\title{
Errata: Marian Chace Foundation Annual Lecture-A Performance by MUSE Celebrating the Cycle of Life with Art, Dance, Music, and Poetry
}

In the article entitled "Marian Chace Foundation Annual Lecture-A Performance by MUSE Celebrating the Cycle of Life with Art, Dance, Music, and Poetry," by Carol Thayer Cox, Vicky Wilder, Peggy Osna Heller, Carolyn Sonnen, and Matthew Bernier, published in American Journal of Dance Therapy, Volume 26, Number 1 (Spring/Summer 2004), pp. 17-42, the following figures were misidentified:

On p. 18: The citation of Figure 1 on line 3 should have appeared on line 13 after the right parenthesis.

On p. 19: Figure 2 is an example of stage 0.

On p. 23: Figure 3 is a drawing of stage 0.

On p. 25: Figure 4 is a visual image for stage 1. 